\title{
Winning the Fight but Losing the Battle: Beyond the Successful Prosecution of Unlawful Carnal Knowledge of the Girl-Child in Nigeria
}

\author{
M. A. AjaNwachuku \\ Dean, Faculty of Law, Ebonyi State University, Abakaliki, Nigeria \\ Email: majanwachuku@yahoo.com
}

Received 10 February 2016; accepted 12 March 2016; published 15 March 2016

Copyright (C) 2016 by author and Scientific Research Publishing Inc.

This work is licensed under the Creative Commons Attribution International License (CC BY).

http://creativecommons.org/licenses/by/4.0/

(c) (i) Open Access

\begin{abstract}
This paper examines the attitude of Nigerian courts to sentencing in the offence of unlawful carnal knowledge of the girl-child. It compares the positions of the two criminal statutes in Nigeria to unveil the sentencing limit allowable in Nigerian criminal jurisprudence and notes that the courts have habitually imposed far lower sentences than contemplated in the statutes. The paper concludes that awarding lighter sentences in cases of child rape in Nigeria has not served to remedy the mischief of male adult taking advantage of the innocence of children to defile them and that such sentencing pattern is against public policy in Nigeria. It recommends the way to correct this anomaly by appellate courts, so as to deter would-be pedophiles in Nigeria.
\end{abstract}

\section{Keywords}

Unlawful Carnal Knowledge, Girl-Child, Prosecution, Sentencing, Nigeria

\section{Introduction}

In Nigeria, there are two criminal jurisdictions consisting of the North (Penal Code, 1963 PC) ${ }^{1}$ and South (Criminal Code Act, 2010 CCA) ${ }^{2}$ substantive, adjectival and case jurisprudence. Both jurisdictions criminalise

\footnotetext{
${ }^{1}$ The Code is applicable in all states of the Northern region of Nigeria including the sates of Adamawa, Bauchi, Benue, Borno, Gombe, Jigawa, Kaduna, Kano, Katsina, Kebbi, Kogi, Kwara, Nasarawa, Niger, Plateau, Sokoto, Taraba, Yobe, Zamfara and Abuja, the Federal Capital Territory of Nigeria.

${ }^{2}$ The Code is applicable in the entire Southern region of Nigeria, which comprise of the former Western, Mid-Western and Eastern regions, (the present states of Abia, Akwa-Ibom, Anambra, Bayelsa, Cross River, Delta, Ebonyi, Edo, Enugu, Ekiti, Imo, Lagos, Ogun, Ondo, Osun, Oyoand Rivers).
}

How to cite this paper: AjaNwachuku, M. A. (2016). Winning the Fight but Losing the Battle: Beyond the Successful Prosecution of Unlawful Carnal Knowledge of the Girl-Child in Nigeria. Beijing Law Review, 7, 51-56.

http://dx.doi.org/10.4236/blr.2016.71006 
unlawful carnal knowledge of the girl-child below a certain age, and provides for punishment of terms of imprisonment in addition to fine or caning. The terms of imprisonment in the two statutes are however, graduated from as low as two years, to as high as life imprisonment. By the provisions of section 277 of the Nigerian Child's Rights Act (CRA, 2010), a child is a person below the age of eighteen years. However, for the purpose of the offence of child rape or unlawful carnal knowledge of the child, the two Codes have lowered the age of the child for which an adult male may be held responsible for the offence of rape. Under the CCA, responsibility for unlawful carnal knowledge of the child is graduated based on the age of the child as follows:

- Girl-child below 11 years. The CCA provides in section 218 that conviction for unlawful carnal knowledge of a girl-child below 11 years attracts imprisonment for life, while conviction for an attempt of it attracts fourteen years imprisonment. Both jail terms are with or without whipping.

- Girl-child up to 11 years but below 13 years. The CCA provides in section 221 that conviction for unlawful carnal knowledge of a girl-child of up to 11 years but below 13 years or an attempt of it attracts two years imprisonment, with or without whipping.

- Girl-child up to 13 years of age and below 18 years are accommodated under the omnibus provision in section 357 of the CCA that punishes for unlawful carnal knowledge of a "girl without her consent", with life imprisonment, with or without whipping. The Code expressly provides that the following do not constitute consent: Consent obtained by force, consent obtained by means of threat or intimidation of any kind, consent obtained by fear of harm or consent obtained by false or fraudulent representation as to the nature of the act.

For reason of the tender age of girl-child as set out in section 218 of the CCA, this paper shall concentrate on unlawful carnal knowledge of a girl-child, below eleven years of age. Under the PC, responsibility for rape of the girl-child is also age dependent as follows:

- Girl-child below fourteen years of age. The PC provides in section 282 that rape includes having sexual intercourse with a girl-child below the age of fourteen years with or without her consent and provides in section 283 that punishment on conviction is life imprisonment or any lesser term and shall include fine.

- Girl-child up to fourteen years of age but below eighteen years of age. The PC accommodated a girl-child of up to fourteen years of age but below eighteen years of age under the omnibus provision in the same section 282 that rape is sexual intercourse with a girl-child that is not under fourteen years of age, "against her will" and "without her consent". The section defines lack of consent to include consent obtained by putting the girl-child in fear of death or by putting the girl-child in fear of hurt. The punishment for conviction of the offence is provided in section 283, as life imprisonment or any less term, in addition to fine.

In the CCA, unlawful carnal knowledge of the girl-child below the age of eleven attracts the maximum term of life imprisonment. The same applies in the PC; however, the age of defilement that attracts the maximum punishment is elevated to below fourteen years. There is no doubt that these levels of punishment are quite high, which demonstrates the seriousness with which the Nigerian society abhors the offence of child defilement. It is argued that the high jail terms are meant to deter would-be offenders from committing the offence; however, while it is contended that the risk of severe punishment decreases the desire to commit crime, this does not explain why these crimes are still prevalent in the society, notwithstanding the punishment (Ritchie 2011). ${ }^{3}$

In exercising the discretion to impose jail terms upon conviction for the offence however, Nigerian courts seem to have abandoned the jurisprudence of the inclusion of the heavy jail terms in both the CCA and PC. ${ }^{4}$ The sentencing pattern of courts, especially courts of first instance in Nigeria indicates that judges prefer to impose light sentences on adult males proven to have defiled minor girls. This inordinate practice of the courts has not only diminished the impact of the heavy punishment on prospect offenders in Nigeria, but has also defeated the aim of the statutory imposition of such jail terms, which is the deterrence of potential offenders. Thus, where proven, conviction of offenders is usually achieved in Nigeria, yet the society is deprived of the opportunity of ridding itself of the menace of child rape because offenders are quickly released back into the society. Ironically, the appellate courts in Nigeria have deplored the practice of light sentences for offenders, but have been unable to remedy such sentences because of procedural and technical difficulties. The purpose of this paper is to analyse decisions of appellate courts in Nigeria to determine the attitude of these courts to the pattern of sentencing by lower courts in the offence of child rape in Nigeria. The paper will specifically consider rape of girl-children

\footnotetext{
${ }^{3}$ The utility of severe punishment to deter potential offenders is still a raging debate amongst sociologists and legal experts. In this paper, we however subscribe to the deterrence theory in order to question the sentencing policy of Nigerian courts with respect to the crime of child rape.

${ }^{4}$ The Penal Code in section 283expresslyempowers the court to impose lesser jail term for the offence of rape.
} 
below the age of eleven years as provided in section 218 of the CCA and below the age of fourteen years as provided in sections 282 and 283 of the PC, applicable in the South and Northern criminal jurisdictions in Nigeria respectively. As there are virtually no researches previously conducted in this area in Nigeria, the author will rely solely on statutory provisions and decided cases to accomplish the purpose of this paper. The paper finally recommends the best way to correct this anomaly by the appellate courts in order to deter would-be pedophiles in Nigeria.

\section{Prosecution of the Offence of Unlawful Carnal Knowledge of the Girl-Child}

Although, the CCA and PC provide for the offence of defilement of the girl-child, this offence is constituted differently in the two statutes. The Constitution of the federal republic of Nigeria (CFRN, 1999) in section 36(12) defines a crime as any act or omission provided in a written law in force in Nigeria for which punishment is stipulated. Thus, notwithstanding the statutory differences in the CCA and PC, the offence of child defilement is a crime for which the court must convict upon adequate evidence. Paradoxically, the essential ingredients for proof of the offence in the two codes are very similar; however, the procedure for arraignment and prosecution differs diametrically. We shall briefly consider these similarities and differences below.

The relevant provisions of the CCA provides as follows:

Any person who has unlawful carnal knowledge of a girl under the age of eleven years is guilty of a felony, and is liable to imprisonment for life...Any person who attempts to have unlawful carnal knowledge of a girl under the age of eleven years is guilty of a felony, and is liable to imprisonment for fourteen years... A prosecution for either of the offences defined in this section must be begun within two months after the offence is committed... A person cannot be convicted of either of the offences defined in this section upon the uncorroborated testimony of one witness (s.218 CCA).

The PC on the other hand provides that:

A man is said to commit rape who... has sexual intercourse with a woman... with or without her consent, when she is under fourteen years of age or of unsound mind (s.282 PC)....Whosoever commits rape shall be punished with imprisonment for life or for any less term and shall be liable to fine (s.283 PC).

A cursory look at the provisions of the two codes reveals that:

- Though, the wordings of the two codes are different, the substances of the provisions are essentially the same. While the CCA uses the term "unlawful carnal knowledge" to describe the act, the PC uses the single word, "rape" to describe the same offence.

- Both Codes provide for punishment on conviction of life imprisonment, although the PC gives the court the discretion to impose a lesser term of imprisonment.

- The CCA, unlike the PC made provision for attempt to commit the offence and provides for time delimitation for commencement of prosecution for the offence.

- The CCA again, without corresponding provision in the PC requires provides corroborative testimony to convict any person for the offence.

It appears from the provisions of the two codes that it is more difficult to convict a person charged under the provisions of the CCA than it is for a person charged under the PC. Nigeria operates an accusatorial system, which presumes the accused person innocent until proven guilty by the prosecution (s.36(5) CFRN 1999). The prosecution cannot rely on the weakness of the defence to secure conviction of the accused person, but must lead credible evidence to prove the allegation brought against the accused (APC v. INEC, 2015); s.131 Evidence Act 2011 EA). Generally, proof does not require the production of a particular type of evidence, nor does it require the production of a litany of witnesses (Ogedengbe v. State, 2014; Obidike v. State, 2014). ${ }^{5}$ However, to secure conviction, the prosecution must prove its case beyond reasonable doubt (Omoleye $v$ State, 2014). These procedural norms are the basic requirements in trials brought under the CCA and PC. In the case of the CCA however, it is impossible to prove and secure conviction for the offence of unlawful carnal knowledge of minors on the uncorroborated testimony of one witness (s.218 CCA). This provision is missing in the PC. Notwithstanding, the practice of the courts in Nigeria has been to require corroboration in all cases of rape because conviction on the

\footnotetext{
${ }^{5}$ (where the court held that "it is not mandatory for the prosecution to call a host of witnesses to prove its case beyond reasonable doubt in a criminal trial... Accordingly, a single witness for the prosecution who gives cogent eye witness account on a vital point suffices”).
} 
evidence of the victim alone is unsafe as the uncorroborated testimony of the prosecutrix may be contrived (Okoh v. Nigerian Army, 2013). ${ }^{6}$ This is supported by the decision of the Supreme Court in Posu v State where the court held that:

as a rule of prudence and settled course of practice, the court should seek for corroboration in all cases of rape. This is so because it has been found to be unsafe to convict for the offence of rape on the uncorroborated testimony of the prosecutrix.

Any type of evidence is sufficient to corroborate the testimony of the victim (prosecutrix) in proof of the offence. In the case of Popoola $v$ State, which involved the confession of the accused person to the police of having had unlawful carnal knowledge of a female high school student, the Supreme Court on the issue of corroboration, stated as follows:

In a trial for rape, evidence of corroboration could come from the accused himself. In this case, the confessional statement of the appellant corroborated the evidence of Prosecution Witness (PW1) (the prosecutrix) that the appellant raped her (Popoola $v$ State, Ratio 3).

Generally, the jurisprudence of criminal trials in common law countries deprecates the conviction of an accused person where there is doubt, no matter how little in the evidence of the prosecution. Every criminal case must be proven beyond reasonable doubt. Any doubt must be resolved in favour of the accused person, because "it is better for ten guilty persons to be set free that for one innocent person to be convicted" (Odogwu v. State, 2013; Anyanwu v. State, 2012). Proof in the case of the offence of unlawful carnal knowledge is established if there evidence of penetration of the private part of the prosecutrix with the male organ of the accused, no matter how slight the penetration might have been and whether or not the hymen was ruptured or there was emission (Ahmed v. Nigerian Army, 2011).

The CCA provides an additional hurdle for the prosecution to scale in allegations of unlawful carnal knowledge of minors. Such an allegation must be charged before a competent court of law within two months of the alleged commission of the offence or attempt to commit it. This requirement is a condition precedent for the trial of an accused persons charged for the offence, as the provision constitutes a binding duty to ensure compliance. ${ }^{7}$ On the other hand, the provisions of the CCA are ambiguous compared to the PC on the issue of consent of the minor to sexual intercourse. It appears from the provisions of section 218 of the CCA that where the accused has "lawful" carnal knowledge of the minor, he may be exonerated from the charge of defilement of the child. This may not be the correct interpretation as the Supreme Court has decided that "a child cannot consent to sex" (Adonike v. State, 2015). Carnal knowledge of a child of below eleven years of age is thus, a priori "unlawful". The PC on its part is express about this in section 282 that "consent" of a child of less than fourteen years of age is not a defence to sexual intercourse. A child does not have the requisite capacity to give consent to sexual intercourse. If however, the child being below sixteen years of age but above the requisite age of criminalization of eleven and fourteen years respectively, the issue of consent is determined by the state of mind of the child, evidencing maturity and knowledge of the nature of act in the absence of force, threat, fraud and intimidation (Popoola v. State at ratio 1).

\section{Sentencing Pattern of Nigerian Courts}

Where the prosecution successfully proves the guilt of the accused, the court must convict the accused and administer the sentence. Conviction means pronouncement of guilt, while sentence means imposition of punishment. We have already seen from the Codes that the sentence for the offence of unlawful carnal knowledge of a girl below eleven years or fourteen years as the case may be, is life imprisonment (s. 218 CCA \& s.283 PC). The PC adequately states the position of the law with respect to the discretion of the court to impose a lesser punishment (s.283 PC). The court is supposed to exercise such discretionary power judicially and judiciously, ${ }^{8}$

\footnotetext{
${ }^{6}$ The Court of Appeal noted that "it is a well-established practice by the courts in Nigeria, that in cases of rape the evidence of the complainant should be corroborated.

${ }^{7}$ On the interpretation of mandatory provision of statute, see the Supreme Court case of Corporate Ideal Insurance Ltd v. Ajaokuta Steel Company Ltd (2014) 17 NWLR [Pt. 1405] 165, ratio 13.

${ }^{8}$ Describing the two words, the Supreme Court in Nigerian Laboratory Corporation v. Pacific Merchant Bank Ltd (2012) 15 NWLR [Pt. 1324] 505 at ratio 3 stated that: "to 'act judicially' means a body is bound to hear evidence from one side and the other. The body would have to hear submissions and evidence by each side and come to a judicial decision appropriately in the way that a court must do. 'Judiciously', on the other hand, means a decision taken which has been directed by sound and sensible judgment”.
} 
which means that it express equitable and satisfactory reasons for the decision to impose a lesserpunishment than the maximum stipulated by law.

Unfortunately, majority of judicial decisions in Nigeria have towed the line of leniency rather than sought to protect public morality by imposing the maximum sentence to deter potential offenders. In awarding jail terms far less than the maximum of life imprisonment, the courts have rendered unserious the severe nature of the crime thereby making a ridicule of the term of life imprisonment provided by the Codes. ${ }^{9}$ For example in Adonike $v$ State (supra) the accused person invited and requested a five-year-old girl to buy sachet water for him. On return, the accused person lured her into his room and had carnal knowledge of her. He was arrested and prosecuted under section 218 of CCA. The court convicted and sentenced him to six years imprisonment, with six strokes of the cane. The accused appealed against his conviction to the Court of Appeal where his conviction was affirmed, for which he further appealed to the Supreme Court. Okoro JSC who read the lead judgment of the Supreme Court affirmed the decisions of the lower courts seriously frowned at the sentence imposed by the trial court in the following words:

The appellant herein was sentenced to six years imprisonment with hard labour and six strokes of the cane. I wish it was more than this...” (at 266).

Concurring with the judgment, Muntaka-Coomassie JSC further deprecated the very diminutive punishment in view of the frequent occurrence of the crime. In his words, he stated thus:

The appellant, a pedophiles deserve no less than to be kept out of circulation... especially against the back drop of the rise in rape cases nowadays... Had the trial Judge and indeed the court below by chance sentenced the accused/appellant to death or life imprisonment I would have kept mum (at 283-284).

The impression given by the Supreme Court in this decision is that the trial court did not exercise its discretion judiciously, especially against the backdrop of the rise in rape cases in Nigeria. Where the appellate court notices a lapse in the exercise of the discretion of the lower court pertaining to the sentence imposed, it can alter the sentence in line with realities taking into consideration the demands of justice and the society. However, for that to happen, there must be a specific cross-appeal by the prosecution against the inordinately low sentence imposed at the lower court. The Nigerian Supreme Court has expressed the desire to remedy the sentences awarded against accused persons who were convicted for the ugly offence of child rape, but have regretted the technical hurdle of having to alter the sentence only on cross-appeal against such sentences by the prosecution. Thus, in the case above, Okoro JSC lamented that:

I wish it was more than this (six years imprisonment and six strokes of the cane) and unfortunately, there is no appeal against sentence... I wish I have the power to increase his punishment. I could have done it in order to serve as deterrence to would-be rapists. Be that as it may, if he does not repent, he may not be as lucky as he was in this case (at 266-267).

In the case of Ezigbo v State (2012), the appellant, aged thirty-two years was in the habit of luring two sisters, aged six and eight years into his shop and making love to them. He was prosecuted for the offence of rape under section 282(1) of the PC. Upon conviction, he was sentenced to two years imprisonment and five hundred naira fine or three months imprisonment on failure to pay the fine. He appealed to the Court of Appeal against his conviction and lost it. At the Supreme Court where his appeal was again dismissed, Muhammad JSC lamented as follows:

Honestly, for an adult man like the appellant to have carnal knowledge of under-aged girls such as the appellant's victims is very callous and animalistic. It is against the laws of all human beings and it is against God and the State. Such small (under-aged) girls and indeed all females of whatever age need to be protected against callous acts of criminality like-minded people of the appellant's class. I wish the punishment was heavier so as to serve as deterrent.

The learned law lords in the above cases merely expressed the condemnation of the society to the heinous nature of the crime of child rape in Nigeria. The sentences imposed were thus, far too low to serve as any deterrence to desire the unnatural act of sexual intercourse with minor girls. Such sentences defeat the aim of inclusion

\footnotetext{
${ }^{9}$ See Posu v. State (supra), ratio 12, (the Supreme Court commented that "unnecessarily lenient and loose" jail terms produces "the unsavory effect of turning rape into a past-time by flippant youths").
} 
of the heavy punishment in the CCA and PC and leads to the phenomenon of winning the fight but losing the battle. However, in Musa v. State (2012) the Court of Appeal refused to alter the sentence of fourteen years imposed on the appellant who was convicted for rape of a seven-year-old girl under section 283 of the PC, because "an appellate court will not interfere with the sentence imposed by a trial court unless it is... wrong in principle". The Court held that the sentence was "proper in the circumstances", and that the trial court had exercised its discretion "judicially and judiciously" having regard to the need to "insulate the society from people such as the appellant” (ratio 15).

\section{Conclusion}

This paper has analysed the legal position of the offence of unlawful carnal knowledge of female children in Nigeria. It compared the provisions in the Penal Code applicable in Northern Nigeria with that of the Criminal Code applicable in the South, and examined the case jurisprudence of these provisions in Nigeria. The paper noted that trial courts are fond of awarding paltry jail terms to convict of this dastard offence, which has not deterred pedophiles from fulfilling their cravings with the innocence of children. We recommend the way forward as the institution of a continuing legal education programme for both judges and state judicial officers on the need to impose the maximum punishment for the offence of child rape.

We further recommend appeal against sentences that are lenient. This is because of the lackadaisical attitude of the prosecution to appeals against sentences considered inadequate. For instance in Ebonyi State of Nigeria, between 2010 to 2015 the courts convicted up to fifteen cases of unlawful carnal knowledge of girl-children below the age of eleven years and imposed paltry sentences of usually less than five years imprisonment. The prosecution did not appeal against any of these sentences. Of course, this trend replicates itself all over the Nigerian federation as shown in the cases reported above from the Court of Appeal and Supreme Court of Nigeria. In fact, between 2010 and 2015 only very few cases were appeals from the High Court to the appellate courts on child rape; yet none of these cases emanated from the prosecution against low sentences by the lower courts. Finally, we recommend a review of the sentencing provisions in our penal legislations to stipulate mandatory minimum sentences for heinous crimes such as child rape, in order to forestall the imposition of lenient sentences by trial courts as observed in this paper.

\section{References}

Ahmed v. Nigerian Army (2011). 1 NWLR [Pt. 1227] 89.

Adonike v. State (2015). 7 NWLR [Pt. 1458] 237, ratio 7.

Anyanwu v. State (2012). 16 NWLR [Pt. 1326] 221 ratio 43 (Court of Appeal)

APC v. INEC (2015). 8 NWLR [Pt. 1462] 531.

Child's Rights Act (CRA), Cap C.50, Laws of the Federation of Nigeria, 2010.

Constitution of the Federal Republic of Nigeria, 1999.

Criminal Code Act, Cap. C.38, Laws of the Federation of Nigeria, 2010.

Ezigbo v State (2012). 16 NWLR [Pt.1326] 318.

Musa v. State (2012). 3 NWLR [Pt.1286] 59.

Obidike v. State (2014). 10 NWLR [Pt 1414] 53, at 104, paras. B-D.

Odogwu v. State (2013). 14 NWLR [Pt. 1373] 74 ratio 17 (Supreme Court).

Ogedengbe v. State (2014). 12 NWLR [Pt. 1421] 338 at 354 paras. F-G.

Okoh v. Nigerian Army (2013). 1 NWLR [Pt. 1334] 16 ratio 5.

Omoleye v State (2014). 3 NWLR [Pt. 1394] 232 ratios 2 \& 3 (Court of Appeal)

Penal Code, Cap 89, Laws of Northern Nigeria, 1963.

Popoola v State (2013). 17 NWLR [Pt. 1382] 96.

Posu v State (2011). 2 NWLR [Pt. 1234] 393 at ratio 11.

Ritchie, D. (2011). Sentencing Matters: Does Imprisonment Deter? A Review of the Evidence. Australia: Sentencing Advisory Council. 